(c) Elsevier/INRA

Note

\title{
Polymorphism of $\beta$-casein in the Creole goat of Guadeloupe: evidence for a null allele
}

\author{
MF Mahé, F Grosclaude \\ Institut National de la Recherche Agronomique, Laboratoire de Génétique Biochimique, \\ 78352 Jouy-en-Josas cedex, France
}

(Received 6 January 1993; accepted 3 February 1993)

Summary - A polymorphism of $\beta$-casein, including several null phenotypes, was observed in a large flock of Creole goats of Guadeloupe. In addition to the common allele, $\beta-\mathrm{Cn}{ }^{\mathrm{A}}$, this polymorphism includes 2 new alleles: $\beta-\mathrm{Cn}^{\mathrm{B}}$ with a frequency of 0.03 and $\beta-\mathrm{Cn}^{\mathrm{O}}$, a null allele with a frequency of $\approx 0.2$. The null allele was found in 2 different $\alpha_{\mathrm{s} 1}-\mathrm{Cn}, \beta-\mathrm{Cn}$ haplotypes: $\alpha_{\mathrm{s} 1}-\mathrm{Cn}^{\mathrm{B}}, \beta-\mathrm{Cn}^{\mathrm{O}}$ and $\alpha_{\mathrm{s} 1}-\mathrm{Cn}^{\mathrm{A}}, \beta-\mathrm{Cn}^{\mathrm{O}}$. This suggests the possible existence of 2 different mutations producing a null allele at locus $\beta$-Cn.

goat / $\beta$-casein / polymorphism / null type

Résumé - Polymorphisme de la caséine $\beta$ dans un troupeau de chèvres créoles de Guadeloupe : mise en évidence d'un allèle nul. Un polymorphisme de la caséine $\beta$, comprenant entre autres plusieurs phénotypes nuls, a été observé dans un grand troupeau de chèvres créoles de Guadeloupe. Ce polymorphisme s'explique par la présence, en plus de l'allèle commun, $\beta-\mathrm{Cn}^{\mathrm{A}}$, de 2 «nouveaux» allèles: $\beta-\mathrm{Cn}^{\mathrm{B}}$ (fréquence :0,03) et $\beta-\mathrm{Cn}^{\mathrm{O}}$, un allèle nul (fréquence d'environ 0,2). L'allèle nul a été trouvé dans 2 haplotypes $\alpha_{\mathrm{s} 1}-\mathrm{Cn}$, $\beta$-Cn différents : $\alpha_{\mathrm{s} 1}-\mathrm{Cn}^{\mathrm{B}}, \beta-\mathrm{Cn}^{\mathrm{O}}$ et $\alpha_{\mathrm{s} 1}-\mathrm{Cn}^{\mathrm{A}}, \beta-\mathrm{Cn}^{\mathrm{O}}$, ce qui suggère l'existence possible de 2 mutations de type nul au locus $\beta$-Cn.

chèvre / caséine $\beta$ / polymorphisme / allèle nul

\section{INTRODUCTION}

Among the 4 types of casein, 3 have been found to be polymorphic in the goat, namely $\alpha_{\mathrm{s} 1^{-}}, \alpha_{\mathrm{s} 2^{-}}$, and $\kappa$-caseins. Boulanger et al (1984) were the first to describe the polymorphism of $\alpha_{\mathrm{s} 2}$-casein with 2 alleles, $\alpha_{\mathrm{s} 2}-\mathrm{Cn}^{\mathrm{A}}$ and $\alpha_{\mathrm{s} 2}-\mathrm{Cn}^{\mathrm{B}}$, the first being predominant in the Alpine and Saanen breeds. Later studies in other breeds 
indicated that this polymorphism was widely distributed (Grosclaude and Tucker, 1992). The polymorphism of $\alpha_{\mathrm{s} 1}$-casein, also disclosed by Boulanger et al (1984), was further investigated by Grosclaude et al (1987) and Mahé and Grosclaude (1989),

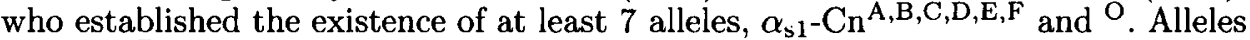
$\alpha_{s 1}-C^{D, E}$ and $F$ are considered as defective mutants in that they are associated

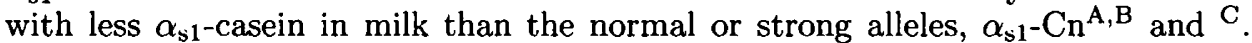
The characterization of the 6 protein variants was carried out by Brignon et al (1989, 1990). Furthermore, it is now suggested that the decreased rate of $\alpha_{\mathrm{s} 1^{-}}$ casein synthesis associated with allele $\alpha_{s 1}-\mathrm{Cn}^{\mathrm{F}}$ is due to altered RNA splicing, as a consequence of an exonic point deletion (Leroux et al, 1992). The 7 th allele $\alpha_{\mathrm{s} 1^{-}}$ $\mathrm{Cn}^{\mathrm{O}}$, is a null allele. In the Alpine and Saanen breeds, the defective alleles $\alpha_{s 1}-C n^{\mathrm{E}}$ and $\alpha_{\mathrm{s} 1}-\mathrm{Cn}^{\mathrm{F}}$ are largely predominant, but in other European breeds, the 'strong' alleles have the highest frequencies (Grosclaude and Tucker, 1992). The existence of a polymorphism of $\kappa$-casein (alleles $\kappa-\mathrm{Cn}^{\mathrm{A}}$ and $\kappa-\mathrm{Cn}^{\mathrm{B}}$ ), as first suggested by Russo et al (1986), was confirmed by Di Luccia et al (1990).

Upon electrophoresis, the 4 th type of casein, $\beta$-casein, reveals the presence of 2 dark and 1 lighter bands. This heterogeneity, as observed in sheep $\beta$-casein (Richardson and Mercier, 1979), is probably due to a different degree of phosphorylation and is not truly a genetic polymorphism. Until now, $\beta$-casein has been considered to be monomorphic in the goat. However, Mácha (1981) made reference to 4 alleles in the Czech White Shorthaired breed but no description was given for this polymorphism. In the Italian Garganica breed, Dall'Olio et al (1989) found a milk sample with no visible electrophoretic band corresponding to $\beta$-casein, but the genetic basis of this phenomenon was not investigated.

We describe here a polymorphism of $\beta$-casein found in the Creole goat of Guadeloupe. This population, which is used for meat production, is supposed to have originated from importations taking place in the 1 th to 19 th centuries from Eastern Africa and India (Chemineau et al, 1984).

\section{MATERIALS AND METHODS}

Individual milk samples were collected from Creole goats bred in the INRA experimental flock (130-150 females) of Gardel, near Le Moule, Guadeloupe (French West Indies). Except for isoelectric focusing (IEF), all other analytical techniques were as described by Grosclaude et al (1987).

Isoelectric focusing was performed according to an adaptation of the procedure of Seibert et al (1985). IEF was carried out in $5 \%$ polyacrylamide gels containing $8 \mathrm{M}$ urea, and a mixture of ampholytes (Pharmacia) consisting of: $1.2 \%(\mathrm{v} / \mathrm{v}$ ), pH 4.2-4.9;0.9\% pH 2.5-5, 0.3\% pH 5-6.5. The skim milk samples were diluted with 4 volumes of distilled water and applied close to the anodic side of the gel. Electrofocusing was carried out with a Multiphor II apparatus (Pharmacia-LKB) in $0.5 \mathrm{~mm}$ thick gels $(240 \times 115 \mathrm{~mm})$. After prefocusing at $14^{\circ} \mathrm{C}$ and constant power $(9 \mathrm{~W})$, focusing was continued for $80 \mathrm{~min}$ at $20 \mathrm{~W}$. During the run, the voltage rose from $350 \mathrm{~V}$ to $2500 \mathrm{~V}$. Gels were stained for $10 \mathrm{~min}$ in a solution containing $0.2 \%(\mathrm{v} / \mathrm{v})$ Coomassie blue G-250, 50\% methanol and $10 \%$ acetic acid in water. Destaining was carried out in an aqueous solution of $30 \%$ methanol, $8 \%$ acetic acid and $10 \%$ glycerol until the background was clear. 


\section{RESULTS}

Among the 127 females present in the flock in 1989,6 lacked the $\beta$-casein fractions in the electrophoretic pattern of their milk as exemplified by sample 7 in figure 1 . Because 3 of the 'null' individuals were offspring of the same male, No 15, the progeny of this sire was used to further investigate the inheritance of the 'null' trait. The $\beta$-casein contents of the milk from 15 available daughters, estimated by rocket immunoelectrophoresis, are given in figure 2 . In addition to the previouslymentioned 3 'null' individuals, 5 more daughters were considered as having inherited the 'null' trait. Assuming that this character originated from the sire (because the dams involved were no longer available to check this inference) the 8:7 ratio, which is not different from the mendelian 1:1 ratio, suggests the existence of a null allele, $\beta$ - $\mathrm{Cn}^{\mathrm{O}}$, at the $\beta$-casein locus. Based on the proportion of homozygous individuals in the flock, a rough estimate of the frequency of $\beta-\mathrm{Cn}^{\mathrm{O}}$ would thus be $0.2(\sqrt{6 / 127})$. Taking this value as the probability of transmission for allele $\beta-\mathrm{Cn}^{\mathrm{O}}$ by the dams, the expected proportions of the 3 genotypes among the progeny of male No 15 would be: $\beta-\mathrm{Cn}^{\mathrm{O}} / \mathrm{O}=1.5 ; \beta-\mathrm{Cn}^{\mathrm{A} / \mathrm{O}}=7.5 ; \beta-\mathrm{Cn}^{\mathrm{A} / \mathrm{A}}=6$ which are not statistically different from the observed figures of $3: 5: 7$.

It is known that the 4 bovine casein loci are closely linked (Grosclaude, 1979). In the goat, Grosclaude et al (1987) concluded that $\alpha_{\mathrm{s} 1}-\mathrm{Cn}$ and $\alpha_{\mathrm{s} 2}-\mathrm{Cn}$ were also linked, whereas the status of $\beta$-Cn and $\kappa$-Cn could not be investigated due to the absence of detectable polymorphism in the latter 2 caseins. In the family of male No 15 , allele $\beta-\mathrm{Cn}^{\mathrm{O}}$ appears to be transmitted together with $\alpha_{\mathrm{s} 1}-\mathrm{Cn}^{\mathrm{B}}$, while $\beta$ - $\mathrm{Cn}^{\mathrm{A}}$ is transmitted with $\alpha_{s 1}-\mathrm{Cn}^{\mathrm{A}}$ (4 informative daughters for each case). The inheritance of $\beta$ - $\mathrm{Cn}^{\mathrm{O}}$ could be further studied in the small families (3-5 offspring) of 4 heterozygous males originating from No 15 (fig 2). Again $\beta-\mathrm{Cn}^{\mathrm{O}}$ was transmitted in association with $\alpha_{\mathrm{s} 1}-\mathrm{Cn}^{\mathrm{B}}$ ( 5 informative daughters). As could be expected, these results confirm that, in the goat, locus $\beta-\mathrm{Cn}$ is linked to $\alpha_{\mathrm{s} 1}-\mathrm{Cn}$ and $\alpha_{\mathrm{s} 2}-\mathrm{Cn}$, as in cattle. However, the existence of a second haplotype including $\beta-\mathrm{Cn}^{\mathrm{O}}, \alpha_{\mathrm{s1}}-\mathrm{Cn}^{\mathrm{A}}$, $-\beta-\mathrm{Cn}^{\mathrm{O}}$, was ascertained in another family (male No 111 ).

In the same flock, 8 individuals had additional 'new' $\beta$-casein patterns. In 1 case (fig 1 , sample 6 ) the $\beta$-casein bands were lighter than normal, and were markedly closer to the cathodic position. In the 7 other cases, the same bands were observed together with the usual $\beta$-casein fractions (fig 1 , sample 5 ). This suggested the existence of an additional $\beta$-casein allele, $\beta-\mathrm{Cn}^{\mathrm{B}}$, a hypothesis supported by the segregation observed in the only available family (male No 7004, transmitting $\beta$ $\mathrm{Cn}^{\mathrm{B}}$ to 3 of its 5 offspring). According to family data, the genotype of sample 6 is $\beta-\mathrm{Cn}^{\mathrm{B} / \mathrm{O}}$, which explains the lighter appearance of $\beta$-casein fractions. The frequency of allele $\beta-\mathrm{Cn}^{\mathrm{B}}$ in the flock was 0.03 .

In starch gel electrophoresis, the $\beta$-casein $B$ bands migrate faster under alkaline $\mathrm{pH}$ and slower in acid $\mathrm{pH}$ than those of $\beta$-casein $\mathrm{A}$. In both conditions, their position is shifted to a distance equivalent to the charge of one phosphate group (not shown). These pecularities suggest that the difference in mobility between $\beta-\mathrm{Cn}^{A}$ and $\beta-\mathrm{Cn}^{\mathrm{B}}$ is due to an extra phosphate group in $\beta-\mathrm{Cn}^{\mathrm{B}}$. 


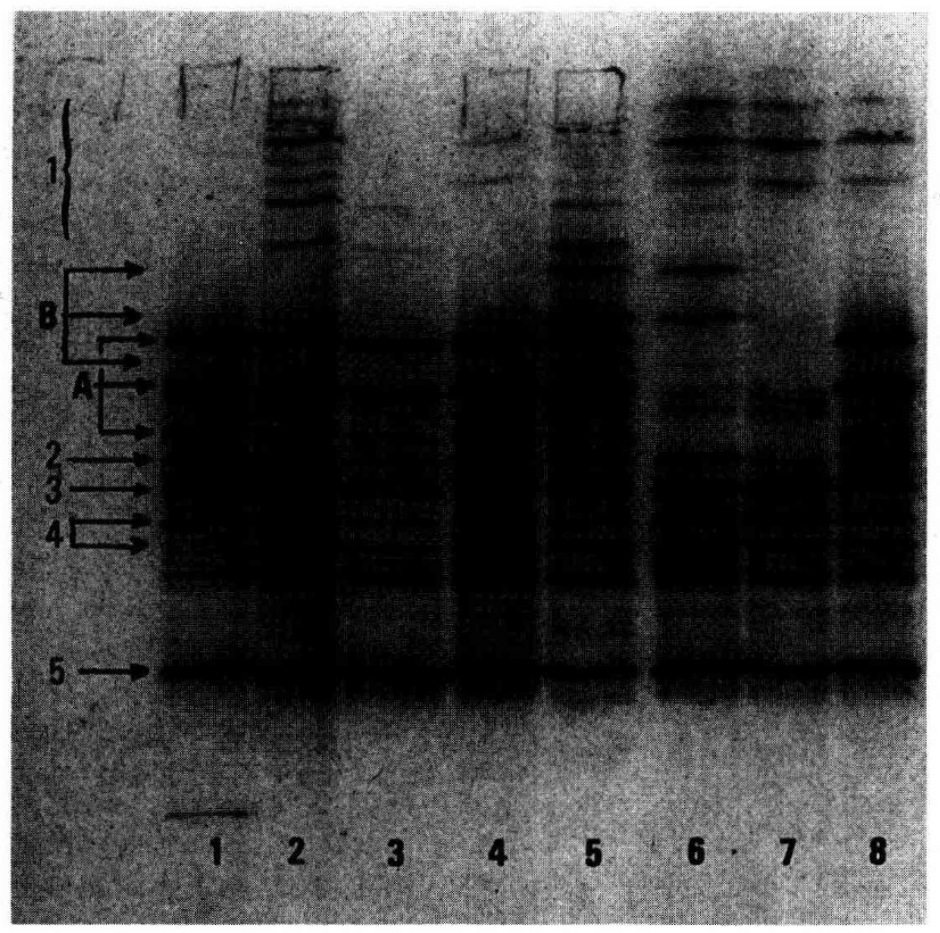

Fig 1. Isoelectric focusing pattern of 8 individual milk samples from Creole goats. The $\beta$-casein fractions corresponding to alleles $\beta-\mathrm{Cn}^{\mathrm{A}}$ and $\beta-\mathrm{Cn}^{\mathrm{B}}$ are indicated by $\mathrm{A}$ and $\mathrm{B}$. The $\beta$-casein genotypes of samples $1-8$ are as follows: $1-4$, and $8: \beta-\mathrm{Cn}^{\mathrm{A} / \mathrm{A}} ; 5: \beta-\mathrm{Cn}^{\mathrm{A} / \mathrm{B}}$; 6: $\beta-\mathrm{Cn}^{\mathrm{B} / \mathrm{O}} ; 7: \beta-\mathrm{Cn}^{\mathrm{O} / \mathrm{O}}$ (null genotype). Numbers located on the left of electrophoretic

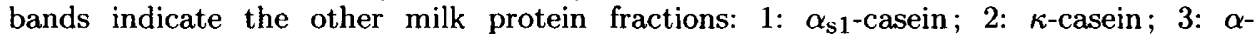
lactalbumin; $4: \alpha_{\mathrm{s} 2}$-casein; $5: \beta$-lactoglobulin. The $\alpha_{\mathrm{s} 1}$-casein genotype of sample 7 is $\alpha_{\mathrm{s} 1}-\mathrm{Cn}^{\mathrm{B} / \mathrm{B}}$; animal 7 was thus homozygous for the haplotype $\alpha_{\mathrm{s} 1}-\mathrm{Cn}^{\mathrm{B}}, \beta-\mathrm{Cn}^{\mathrm{O}}$. The poor resolution of the $\alpha_{\mathrm{s1}}$-casein bands for some samples (1,3 and 4) is due to the low content of $\alpha_{s 1}$-casein in those milks.

\section{DISCUSSION}

Allele $\beta-\mathrm{Cn}^{\mathrm{A}}$ was the only one found in the already investigated breeds. The polymorphism of $\beta$-casein observed in the Creole goat of Guadeloupe is controlled by 2 additional alleles, $\beta-\mathrm{Cn}^{\mathrm{B}}$ and $\beta-\mathrm{Cn}^{\mathrm{O}}$. Although infrequent, the null allele $\beta-\mathrm{Cn}^{\mathrm{O}}$ may be widespread, since a null individual was observed in the Italian Garganica dairy breed (Dall'Olio et al, 1989), and another in the local dairy population of Corsica, France (MF Mahé, 1991, unpublished results). It remains to be established whether all the observed cases were derived from one single or from several mutational event(s).

The existence in the Creole population of 2 different haplotypes including $\beta$ $\mathrm{Cn}^{\mathrm{O}}$ could either be due to the occurrence of 2 independent 'null' mutations, or to 


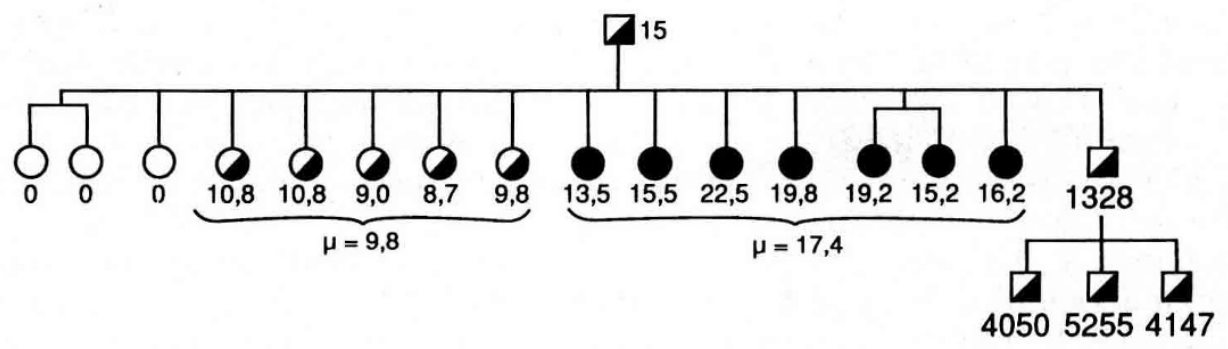

Fig 2. Family of male No 15. Each circle is for a female offspring. The figures below are estimates of the $\beta$-casein content $(\mathrm{g} / \mathrm{l})$ of their milk. Their genotypes are interpreted as follows: light circles: $\beta-\mathrm{Cn}^{\mathrm{O} / \mathrm{O}}$; dark circles: $\beta-\mathrm{Cn}^{\mathrm{A} / \mathrm{A}}$; composite circles: $\beta-\mathrm{Cn}^{\mathrm{A}} / \mathrm{O}$. The squares are for a son and 3 grandsons, all having the genotype $\beta-\mathrm{Cn}^{\mathrm{A} / \mathrm{O}}$.

1 single mutation, transferred into a second haplotype by recombination. In cattle, linkage disequilibrium between alleles of the $\alpha_{\mathrm{s} 1}-\mathrm{Cn}$ and $\beta-\mathrm{Cn}$ loci is particularly strong (Grosclaude, 1979). Most probably, the situation in the goat is similar and consequently, one would be inclined to favour the hypothesis of 2 different mutations. This question may be considered in the light of what is presently known about the null allele of goat $\alpha_{\mathrm{s} 1}$-casein, $\alpha_{\mathrm{s} 1}-\mathrm{Cn}^{\mathrm{O}}$, found by Grosclaude et al (1987). In this case, recent DNA studies have established that there are in fact 2 different $\alpha_{\mathrm{s} 1}$-casein null alleles, $\alpha_{\mathrm{s} 1}-\mathrm{Cn}^{\mathrm{O}_{1}}$, and $\alpha_{\mathrm{s} 1}-\mathrm{Cn}^{\mathrm{O}_{2}}$, characterized by clearly different mutations (C Leroux and Y Amigues, personal communication).

The null $\beta$-casein allele is the sixth example of a defective mutant in the cluster of goat casein loci, in addition to the 5 already identified at the $\alpha_{\mathrm{s} 1}-\mathrm{Cn}$ locus $\left(\alpha_{\mathrm{s} 1}-\right.$ $\left.\mathrm{Cn}^{\mathrm{D}, \mathrm{E}, \mathrm{F}, \mathrm{O}_{1}, \mathrm{O}_{2}}\right)$. The reasons for such an accumulation of defective alleles in the goat, which is not observed in the cow, remain unclear.

\section{ACKNOWLEDGMENTS}

We thank J Fleury, G Alexandre, A Xandé and their coworkers, Domaine expérimental de Gardel and Station de Zootechnie, INRA, Guadeloupe, for providing us with the milk samples and pedigree information.

\section{REFERENCES}

Boulanger A, Grosclaude F, Mahé MF (1984) Polymorphisme des caséines $\alpha_{\mathrm{s} 1}$ et $\alpha_{\mathrm{s} 2}$ de la chèvre (Capra hircus). Génét Sél Évol 16, 157-176

Brignon G, Mahé MF, Grosclaude F, Ribadeau-Dumas B (1989) Sequence of caprine $\alpha_{\mathrm{s} 1}$-casein and characterization of those of its genetic variants which are synthesized at a high level, $\alpha_{\mathrm{s} 1}-\mathrm{Cn}$ A, B and C. Protein Seq Data Anal 2, 181-188

Brignon G, Mahé MF, Ribadeau-Dumas B, Grosclaude F (1990) Two of the three genetic variants of goat $\alpha_{\mathrm{s} 1}$-casein which are synthesized at a reduced level have an internal deletion possibly due to altered RNA splicing. Eur $J$ Biochem 193, 237-241 
Chemineau P, Cognié Y, Xandé A, Peroux F, Alexandre G, Lévy F, Shitalou E, Beche JM, Sergent D, Camus E, Barré N, Thimonier J (1984) Le "Cabrit créole" de Guadeloupe et ses caractéristiques zootechniques: monographie. Rev Elev Méd Vét Pays Trop 37, 225-238

Dall'Olio S, Davoli R, Russo V (1989) Una nuova variante di caseina caprina. Sci Tec Latt Casearia 40, 24-28

Di Luccia A, Mauriello R, Chianese L, Moio L, Addeo F (1990) $\kappa$-casein polymorphism in caprine milk. Sci Tech Latt Casearia 41, 305-314

Grosclaude F (1979) Polymorphism of milk proteins: some biochemical and genetical aspects. In: Proc 18th Int Conf Anim Blood Groups Biochem Polym. Leningrad, 14-18 August 1978, vol 1, 54-92

Grosclaude F, Mahé MF, Brignon G, Di Stasio L, Jeunet R (1987) A Mendelian polymorphism underlying quantitative variations of goat $\alpha_{\mathrm{s} 1}$-casein. Génét Sél Évol $19,399-412$

Grosclaude F, Tucker EM (1992) Blood and milk proteins polymorphism in goat. In: Proc 5th Int Conf on Goats (Lokeshwar RR, ed) New Dehli, 2-8 March 1992, vol 2, 71-84

Leroux C, Mazure N, Martin P (1992) Mutations away from splice site recognition

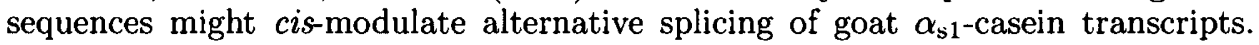
Structural organization of the relevant gene. J Biol Chem 267, 6147-6157

Mácha J (1981) Genetical polymorphism of protein in the milk of goats and performance of goats. Acta Univ Agric (Brno) Fac Agron 29, 233-237

Mahé MF, Grosclaude $\mathrm{F}(1989) \alpha_{\mathrm{s} 1}-\mathrm{Cn}^{\mathrm{D}}$, another allele associated with a decreased synthesis rate at the caprine $\alpha_{\mathrm{s} 1}$-casein locus. Génét Sél Évol 21, 127-129

Richardson BC, Mercier J-C (1979) The primary structure of the ovine $\beta$-caseins. Eur J Biochem 99, 285-297

Roberts B, Ditullio P, Vitale J, Hehir K, Gerdon K (1992) Cloning of the goat $\beta$-casein gene and expression in transgenic mice. Gene 121, 255-262

Russo V, Davoli R, Dall'Olio S, Tedeschi M (1986) Ricerche sul polimorfismo del latte caprino. Zoot Nutr Anim 12, 55-62

Seibert B, Erhardt G, Senft B (1985) Procedure for simultaneous phenotyping of genetic variants in cow's milk by isoelectric focusing. Anim Blood Groups Biochem Genet 16, 183-191 